\begin{tabular}{r} 
SZENTE Viktória \\
HORVÁTH Jolán \\
\hline Kaposvári Egyetem \\
Gazdaságtudományi Kar
\end{tabular}

Marketing és Kereskedelem Intézeti Tanszék (University of Kaposvár, Faculty of Economic Sience, Department of Marketing and Trade) H-7400 Kaposvár, Guba Sándor utca 40.

e-mail: jolan.horvath93@gmail.com

${ }^{1}$ ORCID 0000-0001-5446-8280

https://doi.org/10.33567/etm.2259

\section{A SZOKVÁNYOS ÉS AZ ÖKOÉLELMISZEREK MEGKÜLÖNBÖZTETÉSE ÉRZÉKSZERVI JELLEMZŐK ALAPJÁN}

\author{
DIFFERENTIATING ORDINARY AND ORGANIC FOODS \\ BASED ON ORGANOLEPTIC PROPERTIES
}

The organoleptic properties of food products - especially taste - are important for consumers. Various food processing methods might influence these properties significantly. In our study we were looking for differences between common food products and food products from organic production. We aimed at making contributions to increasing the market potential of organic foods by referring to their product value and product experience. In our qualitative study, initially, we made a personal interview with a nutritionist followed by two focus group interviews. During the quantitative research, milk and bread samples from conventional and from organic producers were tested by 40 participants in blind tests. From the results of the primary research we can conclude that it is possible to distinguish between the products of the two production methods. According to the nutritionist and the participants of the two focus groups there are huge differences between ordinary and organic foods with regards to their nutrition value and their taste while from the outside it is the trademark that can help identify the organic products. In the blind test of milk samples the evaluation of the organic products exceeded that of the ordinary ones. Testers considered the organic milk richer in taste and sweeter than ordinary milk and also a more intensive colour and a fattier texture were reported. Regarding the bread samples, testers preferred the organic ones. They evaluated their colour to be more intensive and their texture denser and more flexible. Consequently, it is relevant to emphasize the differences between the two methods of production during sales. The organoleptic properties of organic food products can be suitable for promoting the positive image of the trademark but further research in needed.

Keywords: fogyasztói preferenciák, érzékszervi teszt, ízészlelés, kenyér, tej (consumer preferencies, organoleptic test, taste perception, bread, milk)

JEL-kód: Q13, M31

\section{BEVEZETÉS - INTRODUCTION}

Napjainkban egyre inkább előtérbe kerül az egészséges táplálkozás az emberek körében. Az étrend összeállításában ezért fontosabb szerepet kapnak a jó minőségü, magas táplálóanyag-tartalmú alapanyagok. Ennek eredményeként növekszik az igény olyan élelmiszerek iránt, amelyek képesek ezeket a megváltozott szükségleteket kielégíteni (Tisza, 2016). Ennek az elvárásnak a felmérések szerint az ökoélelmiszerek megfelelnek (Haas, Sterns, Meixner, Nyob, \& Traar, 2013; Thøgersen, Pedersen, Paternoga, Schwendel \& Aschemann-Witzel, 2017; Pawel, 2016; Szente $\&$ Torma, 2015), hiszen a fogyasztók a visszajelzések alapján magas minőségű tápláléknak tartják azokat. A fogyasztók különösen nagy jelentőséget tulajdonítanak az egészségességnek, hi- szen a többség (75,4\%-a) kifejezetten fontosnak véli azt, tehát a fogyasztást is elsődlegesen az egészséges életmód iránti érdeklődés ösztönzi (Szente, Szakály, \& Széles, 2011; Hofer, 2009). A kutatások rámutatnak arra, hogy a fogyasztók nagy része hallott már a bioélelmiszerekről. Alkalmanként vásárolják is ezeket a termékeket, de a rendszeres fogyasztók aránya alacsonynak mondható. Ennek oka többek között a magas ár, a beszerzési hely és az ismeretek hiánya (Panyor, 2007; Németh-T., Vincze-Tóth, Hegyi \& Troján, 2014; Pawel, 2016). A Nielsen piackutató vállalat 2010-ben készült online felmérésének eredménye alapján megállapítható, hogy biotermékeket minden nyolcadik fogyasztó szokott vásárolni, ami 13\%-ot képvisel az összes fogyasztásból (Gergely, Szabó \& Balázs, 2014). Az ökotermékek elutasítása következtében a fogyasztóknak nincsenek tapasztalatai azok érzékszervi tulajdonságairól. 
$\mathrm{Az}$ organoleptikus tulajdonságok viszont jelentős szerepet képviselnek a fogyasztási és vásárlási szokások kialakításában. Az élelmiszer-előállítók számára komoly kihívást jelent ezért az a kérdés, hogyan lehet pontos adatokat és információkat kapni a potenciális fogyasztóktól, amelyek irányt mutathatnak a termékfejlesztéshez, az értékesítési promócióhoz vagy éppen a folyamatos minőségfejlesztéshez (Duxbury, 2005).

$\mathrm{A} z$ öt érzékszervünk közül az ízlelés elsősorban a vásárlóban kialakult kép formálásához járul hozzá és megerősítheti a márkaidentitást (Hultén, 2015). Lindstrom (2005) az ízlelés és az adott márka vásárlói lojalitása között talált szoros összefüggést, az általa bevezetett márkahűségindex (Brand Loyality Index Score) értéke 19 volt, jelentősen megelőzve a másik négy érzékszerv pontszámát. A kutatás során egyértelműen az érzékek egymásra épülését figyelték meg, és sokat mondó, hogy az íz lehet a döntő szempont egy termék folyamatos választásakor. Különösen lényeges mondanivalója van a kapott eredményeknek az ökoélelmiszerek esetén, ahol a vevők az ízletességet tartják a legfontosabb termékjellemzőnek (Szente, 2004; Pawel, 2016; Huszka \& Polereczki, 2008; Dörnyei, 2008; Fillion \& Arazi, 2002).

A potenciális fogyasztók döntéseit befolyásolja még, hogy nem tudják megkülönböztetni egymástól az organikus és a szokványos élelmiszereket. A csomagoláson található védjegyek viszont már egyértelműen segítik a termékek megkülönböztetését. A z ökocímkék általában pozitívan befolyásolják az íz, valamint az illat megítélését, de a magasabb élvezeti értéket csak fogyasztás útján lehet igazolni (Kiss, Kontor, \& Kun, 2016; Dörnyei, 2008).

$\mathrm{A} z$ erre irányuló organoleptikus különbségek feltárása - a szokványos és az ökoélelmiszerek közötti is - már több tanulmány központi témáját képezi. Ezek közül kiemelkedő az, amelyet Annett és szerzőtársai végeztek 384 fogyasztók bevonásával. A konvencionális és az organikus kenyérminták tulajdonságait vakteszten és a címkék ismeretében is értékelték a bírálók. $\mathrm{Az}$ eredmények alapján a fogyasztók mindkét esetben magasabb élvezeti értékűnek találták a biokenyeret, mint a konvencionális kenyeret (Annett, Muralidharan, Boxall, Cash \& Wishmer, 2008). Fillion és munkatársa kutatásukban arra keresték a választ, hogy az ökológiai gazdálkodásból származó narancslé, illetve tej valóban ízletesebbek-e, mint a szokványos élelmiszerek. A vizsgálatok azt mutatták, hogy a fogyasztók ízletesebbnek találták az organikus narancslevet a szokványossal szemben. Különbséget viszont a tej érzékszervi megítélése során nem találtak (Fillion \& Arazi, 2002). Hazánkban hasonló érzékszervi kutatást a két választott termék esetén nem találtunk. Ezért a célkitüzésünk az volt, hogy feltárjuk a szokványos és az ökotermékek között érzékelhető különbségeket fogyasztói tesztek alapján a teljes kiőrlésű kenyér és a tej esetében, és az eredmények révén hozzájáruljunk az ökoélelmiszerek piaci lehetőségeinek növeléséhez.

A közleményben a szerzők az organikus, öko-, bio- és ökológiai élelmiszereket szinonimaként alkalmazzák, és minden esetben ellenőrzött keretek között előállított és tanúsított ökotermékeket értenek alatta. Szokványos, illetve szinonimaként használt konvencionális élelmiszernek pedig azokat tekintjük, amelyeket szokványos üzemi körülmények, jellemzően vegyszerek felhasználásával és az általános élelmiszerminőségi paraméterek szerint állítottak elö.

\section{ANYAG ÉS MÓDSZER}

A kutatómunka során először szekunder források tanulmányozására volt szükség. Az információk feldolgozása, értékelése megfelelő kiindulási alapot jelentett a vizsgálni kívánt terület behatárolásához. A szekunder kutatás után primer vizsgálatokkal gyüjtöttünk információkat. Ennek során kvalitatív és kvantitatív eljárást is alkalmaztunk.

Először egy szakértői mélyinterjúra került sor dietetikus szakemberrel, aki a témakör táplálkozási lehatárolásában volt segítségünkre. A kiválasztott személy egy nagyvárosban élő, az ökoélelmiszerekkel kifejezetten foglalkozó szakértő volt. Az interjúvázlatban 14 kérdés szerepelt. A beszélgetés elején az általános jellegű kérdésektől kezdve fokozatosan a központi téma felé haladtunk. Az adatfelvétel személyesen történt, hangfelvétel segítette az elmondottak pontos rögzítését és visszahallgatását, majd az elhangzottak feldolgozását.

Ezt követően történt meg a két fókuszcsoportos interjú, amelyen csoportonként 8-8 fó vett részt. Egyik csoportban 30 év alattiak vettek részt, míg a másik csoportba 30 év feletti dolgozó nők kerültek. Mindkét interjú Kaposváron zajlott munkaidőt követően, a felkért személyekkel az időpontot és a helyet előzetesen egyeztettük. Kritériumként az egészséges életmód iránti érdeklődést fogalmaztuk meg, valamint hogy az illető nem vett részt az elmúlt 6 hónapban hasonló témájú vizsgálaton.

Kvantitatív eljárásként egy kísérlet lebonyolítására került sor. Az összesen 40 fő laikus bíráló közül 23 csoporttag nő és 17 férfi volt. A városi lakóhellyel rendelkező bírálók 27-en, míg a falusiak 13-an voltak. A korösszetételt tekintve 22-en 25 év alattiak, míg 18-an 25 év felettiek voltak. A vakteszt során a fogyasztóknak nem volt lehetősége az élelmiszerek csomagolásának megtekintésére. Így egyrészről kizárhatóvá vált a márkahüségből, korábbi negatív/pozitív tapasztalatból, illetve különböző vásárlási, fogyasztási szokásokból fakadó döntéshozatal. A résztvevőknek saját érzékszerveikre hagyatkozva, kóstolás útján kellett döntéseiket meghozniuk. A kísérlet során a jelenlévők számára két eltérő előállítási mód termékeit biztosítottuk. Az eljárás célkitűzése volt, hogy feltárja a hagyományos és bioélelmiszerek között érzékelhető különbségeket. A fogyasztók nem kaptak elözetes ismereteket arról, hogy melyik a hagyományos, illetve melyik az ökoélelmiszer. A kóstolás folyamán a mintákat ugyanolyan színű és méretű edényben osztottuk ki, a megkülönböztetést csupán „A” és „B” jelzés segítette elő. Így volt biztosított az elfogulatlan, szubjektív döntési folyamat. A vakteszt tárgyát képező termékek meghatározásakor arra törekedtünk, hogy olyan élelmiszereket válasszunk ki, amelyeket a bírálatba bevont személyek lehetőség szerint ismernek és fogyasztanak. Ezért esett a választásunk a tejre és a kenyérre, mert mind a két termék az alapélelmiszereink közé tartozik. A tejtermékek esetében a Tolle 2,8\%-os zsírtartalmú ESL tejet, a biotejek közül a Spar Natur Pur bio ESL, szintén 2,8\%-os zsírtartalmú termékét választottuk. A kenyerek közül az egy üzletben elérhető VITA-Sütő Kft. és a Spar Natur Pur bio teljes kiőrlésű kenyerét választottuk.

A vakteszt során a mérhetőséget bírálati lap (ötfokozatú skálát alkalmaztunk a preferenciák mérése érdekében) biztosította, amelynek másik oldalán egy kérdőív szerepelt zárt kérdésekkel, háttérváltozókkal. 
A mintavétel minden esetben elbírálással (nem véletlenszerüen) történt, a reprezentativitás nem volt biztosított, eredményeink ezáltal csak a vizsgált populációra kivetíthetők, azonban más kutatások számára alapozók, modellszerűek lehetnek.

$\mathrm{A} z$ adatok feldolgozása Microsoft Excel programcsomag segítségével történt.

\section{EREDMÉNYEK ÉS ÉRTÉKELÉSÜK}

Ebben a fejezetben a három különböző vizsgálat eredményeit mutatjuk be.

\subsection{Mélyinterjú}

A szakértői mélyinterjú célja volt, hogy táplálkozástudományi vonatkozásban tárjuk fel a bioélelmiszerek étkezésben betöltött szerepét, megítélését az érzékszervi tulajdonságok tekintetében. A dietetikus az ökoélelmiszerek szerepét az egészséges étkezésben pozitívnak ítélte meg. A szakember úgy fogalmazott, hogy „környezetünk és saját egészségünk miatt is jobb fogyasztani." A fogyasztási szokások kialakulásában pedig a legfontosabbnak a családi példamutatás szerepét említette. Miszerint „otthon kellene elkezdeni az egészségnevelést a lehető leghamarabb." A konvencionális és a biogazdálkodás termékei közötti megkülönböztetést külsőleg a „csomagolás segítheti, leginkább a logo.” A beltartalmi mutatókat tekintve is nagy eltérések vannak (pl.: növényvédő szer, polifenol, szárazanyag-tartalom). Az élvezeti érték terén is lehetnek differenciák, amit a termesztés és feldolgozás módja alapvetően meghatároz. A dietetikus szerint „az íz nagyban függ a hozzá adott füszerek, tartósítószerek, ízfokozók használatától." A bioélelmiszerek fogyasztásának növelését több oldalról is megközelítette a szakember. Az egyik ilyen lehetőség, hogy egészségnapokon a gyártók tájékoztathatnák a résztvevőket, hogy hogyan termelik ezeket az élelmiszereket. A reklámokban pedig meghökkentő módszereket kellene alkalmazni. Emellett a könnyebb elérhetőség és a bővebb kínálat is sokat segítene, ami már az utóbbi években javulni látszik. A kereslet növekedését a fogyasztók körében az árak csökkenése ösztönözné a leginkább.

\subsection{Fókuszcsoportos interjúk}

A fókuszcsoportos interjúk elsődleges célja volt, hogy feltárja a résztvevők véleményét a konvencionális és ökotermékek megkülönböztetésének lehetőségeiről. Elsőként az egészséges élelmiszerekről esett szó. Mindkét csoport tagjai egyetértettek abban, hogy az otthon megtermelt élelmiszerek egészségesebbek, mint a bolti termékek. Az eredet ismerete, valamint a nyomon követhetőség egyaránt fontosnak bizonyultak. A csoporttagok ezután bioélelmiszer-fogyasztásukkal kapcsolatosan osztottak meg információkat. A 30 éven aluliak többsége már korábban vásárolt ilyen termékeket, míg a 30 éven felüli tagok fele emlékezete szerint még nem vett bioélelmiszert. A fókuszcsoportos résztvevők fogyasztása tehát korántsem nevezhető rendszeresnek. A válaszadásokból egyúttal $a z$ is kiderült, hogy a jelenlévők döntő többsége nincs tisztában az ökoélelmiszerek fogalmával, hiszen a „háztáji” termékeket azonosítják az organikus árucikkekkel. A megszokott élelmiszerek helyett mindenki szívesen megkóstolná a bioélelmiszereket, mert így megtapasztalhatnák, hogy valóban van-e eltérés a két különböző termelési mód termékei között. Előzetes meglátásaik alapján táplálkozásbiológiai és érzékszervi előnyöket, főként jobb ízélményt várnának el. Egy-egy élelmiszer kiválasztásánál nemcsak a csomagolás fontos a résztvevők számára, hanem az organoleptikus jellemzők is. Az ízletesség megállapítása pedig több tényező függvénye. Egyesek szerint a termelési mód, a frissesség, a tápanyagok és vegyszerek mennyisége, míg mások úgy látják, hogy az adalékanyagok felelősek azért, hogy az egyik ételt finomabbnak érezzük, mint a másikat.

A következő kérdésre adott válaszok igen jól körvonalazták, hogy melyek azok a tényezők, amelyek a bioélelmiszerek fogyasztását meggátolják. A magas ár, hiányos információk, bizalom kérdése, beszerzési hely és a kínálat is elhangzott. Az információk hiánya és a bizalmatlanság több oldalról is megjelent. Ide sorolható a szokványos és a bioélelmiszerek nehézkes megkülönböztethetősége, a csomagolás információtartalma és a nyomon követhetőség kérdése. A bioélelmiszer-fogyasztást a csoporttagok véleménye alapján leginkább az ár csökkenése motiválná. Az orvos/dietetikus, család javaslata és az információk bővülése is kedvezően befolyásolná a fogyasztást.

A következőkben azt kellett megfogalmazniuk a jelenlévőknek, hogy a konvencionális és a biotermékek között milyen különbségek lehetnek. Úgy vélték, hogy az organikus élelmiszerek vegyszermentesek, vitamin- és ásványianyag-tartalmuk magasabb, érzékszervi tulajdonságaik kedvezőbbek. A csoporttagok szerint a zöldségeknél, gyümölcsöknél, tejnél és pékáruk esetében kifejezett különbségek lehetnek. A 30 éven felüli csoporttagok példákat is említettek. A biotej esetében zsírosabb állagot, illetve jobb illatot feltételeznek. A pékáruk esetében úgy vélték, hogy az ökotermékek tömörebb állagúak, ropogósabbak, illatosabbak és ízletesebbek a szokványos árukhoz képest.

\subsection{Vakteszt}

A bírálat előtt a résztvevőkkel ismertettük a kísérlet célját, folyamatát és a bírálati lapok, valamint a kérdőívek kitöltésének menetét. Ezután előkészítettük, majd kiosztottuk a mintákat és a tesztlapokat. A jelenlévők tudták, hogy a vakteszt során mind a két termékcsoport (tej, kenyér) esetében egy bio és egy nem bio mintát kell érzékszervi jellemzők alapján értékelniük. A kóstolás első felében tehát a csoportok tagjai összehasonlították a különböző gazdaságokból származó mintákat. A jelenlévők számára nem tettük lehetővé, hogy a termékek csomagolását megtekintsék. A mintákat úgy készítettük elő, hogy a résztvevők nem látták, melyik jelzésű pohárba kerülnek az adott termékminták. A megkülönböztetést csupán „A” és „B” jelzés segítette elő. Mind a két termékcsoportnál az „A" jelü minta volt a szokványos, illetve a „B” jelü a biogazdálkodásból származó élelmiszer. A tej- és a kenyérértékelő lapokon az érzékszervi tulajdonságokhoz további jellemzők voltak rendelve, melyeket a csoporttagok egy ötfokozatú skálán értékelhettek (ahol: 1 - egyáltalán nem jellemző, 5 - teljes mértékben jellemző). A vakteszt során kapott eredményeket a tejminták esetében az 1 . táblázat szemlélteti. 
1. táblázat: $A$ tej minták érzékszervi jellemzőinek bírálata $(\mathrm{N}=40)$

\begin{tabular}{|c|c|c|c|}
\hline & & „A" Szokványos & „B” Bio \\
\hline \multirow{5}{*}{$\tilde{I} z$} & Tej ízének intenzitása & 4,03 & 4,13 \\
\hline & Édeskés íz & 3,30 & 3,45 \\
\hline & Savanykás íz & 1,85 & 1,70 \\
\hline & Telt íz & 3,73 & 3,55 \\
\hline & Idegen íz & 1,20 & 1,28 \\
\hline \multirow{4}{*}{ Illat } & Tej illatának intenzitása & 3,45 & 3,30 \\
\hline & Édeskés illat & 2,90 & 2,95 \\
\hline & Savanykás illat & 1,63 & 1,53 \\
\hline & Idegen illat & 1,30 & 1,18 \\
\hline \multirow{2}{*}{ Szin } & Tej színintenzitása & 4,28 & 4,35 \\
\hline & Tejre jellemző szín & 4,65 & 4,50 \\
\hline \multirow{4}{*}{ Állomány } & Egynemü & 4,20 & 4,28 \\
\hline & Zavaros & 1,28 & 1,13 \\
\hline & Vizes & 2,30 & 1,85 \\
\hline & Zsíros & 2,40 & 2,95 \\
\hline
\end{tabular}

Az íz vonatkozásában öt különböző tulajdonságot ítéltek meg a bírálók. Elsőként az adott minta ízének intenzitását, majd ezután azt kellett megállapítaniuk, hogy mennyire édeskés, illetve savanykás az ízérzet és végül a teltségét és esetleg idegen ízét. A résztvevők utóiz-érzékelése esetén saját szavaikkal fogalmazhatták meg véleményüket. A csoporttagok értékelése alapján a két minta közül a biotej volt az intenzívebb ízü, emellett édeskésebbnek is bizonyult. Az íz teltségét viszont jobbnak érezték a résztvevők a szokványos minta esetében. Idegen ízt a bírálók a biogazdaságból származó mintánál állapítottak meg inkább. A 40 fós csoportból összesen hárman tapasztaltak utóízt. Kettő fö az „A” jelü minta esetén lisztes ízhatásról számolt be, egy fó pedig mindkét minta esetén finom, édeskés utóízt érzett.

Az illat meghatározásánál négy tulajdonság szerepelt, ahol az intenzitás megítélése kedvezőbben alakult a konvencionális minta esetében. A csoporttagok savanykásabbnak vélték a szokványos mintát és az idegen illat érzékelése is itt érvényesült erőteljesebben. A biotej esetében pedig édesebb illatot tapasztaltak.

$\mathrm{A} z$ állomány tekintetében szintén négy sajátosság alapján kellett jellemezniük a csoporttagoknak a termékeket. A minták értékelése során a biotejet homogénebbnek, a szokványos terméket pedig zavarosabbnak érezték a résztvevők. Emellett úgy gondolták a bírálók, hogy a konvencionális tej vizesebb, míg az ökotej zsírosabb állagú.

A csoport tagjainak az érzékszervi tulajdonságok megítélése mellett a mintákat értékelniük kellett aszerint is, hogy összességében hogyan ítélték meg, illetve mennyire kedvelték az adott terméket. A tejminták megítélésének és kedveltségének alakulását az 1 . ábra mutatja be.

\section{1. ábra: A tejminták megítélése és kedveltsége ötfokozatú skálán $(\mathrm{N}=40)$}

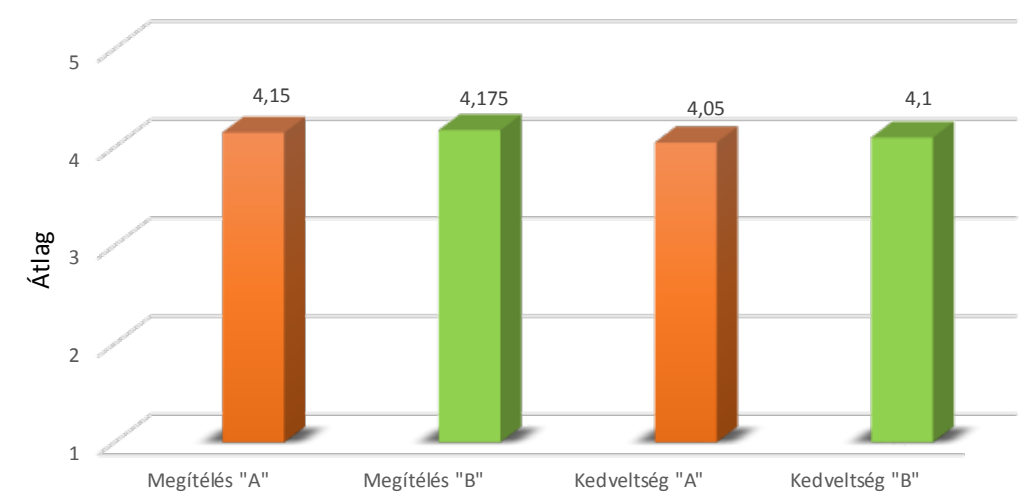


$\mathrm{A} z$ ábra adatai szerint a megítélés során az ökotejet vélték jobbnak a bírálók. A kedveltség tekintetében is a „B” jelü, biogazdálkodásból származó tejet preferálták inkább a résztvevők a konvencionálissal szemben.

A kérdőívben szereplő kérdések során a válaszadóknak a vakteszt alapján meg kellett határozniuk, hogy melyik mintát találták jobbnak, és melyiket vásárolnák meg szívesebben. A 40 főből 22 -en a konvencionális tejet és 18 -an pedig a biotejet részesítették előnyben. A felárfizetési hajlandóságot tekintve az előbbiekhez hasonlóan alakult az arány, hiszen a szokványos termékért 22 fó, míg a biotejért 18 fó fizetne magasabb árat. A származás ismerete nélkül a válaszadók fele (20 fö) helyesen úgy vélte, hogy az "A" jelzésü minta konvencionális és a „B” jelzésű minta biogazdálkodásból származik. Az eredet ismerete pedig 7 személy esetében befolyásolta a vásárlási hajlandóságot. A vakteszt alapján 4 személy a szokványos tejet vásárolta volna meg, de miután megtudták, hogy a másik minta volt az organikus termék, megváltoztatták véleményüket. A vakbírálat során 3-an viszont a biotejet vásárolták volna meg, majd a származás ismeretében inkább a konvencionális terméket választották. A résztvevők azzal indokolták döntésüket, hogy az ökotermékekért magasabb árat kell fizetni.

A tejminták kóstolása, értékelése után a kenyérminták öszszehasonlítása következett. A vakbírálat eredményeit a 2. táblázat mutatja be.

2, táblázat: A kenyérminták érzékszervi jellemzőinek bírálata $(\mathrm{N}=40)$

\begin{tabular}{|c|c|c|c|}
\hline & & $\begin{array}{c}\text { "A" } \\
\text { Szokványos }\end{array}$ & $\begin{array}{l}\text { "B" } \\
\text { Bio }\end{array}$ \\
\hline \multirow{3}{*}{$\hat{I} z$} & Íz intenzitása & 3,68 & 4,05 \\
\hline & $\begin{array}{l}\text { Kenyértípusra } \\
\text { jellemző íz }\end{array}$ & 3,98 & 4,13 \\
\hline & Idegen íz & 1,45 & 1,33 \\
\hline \multirow{2}{*}{ Illat } & Illat intenzitása & 3,88 & 3,65 \\
\hline & Idegen illat & 1,40 & 1,25 \\
\hline \multirow[b]{2}{*}{ Szin } & Szín intenzitása & 3,90 & 4,18 \\
\hline & $\begin{array}{l}\text { Kenyértípusra } \\
\text { jellemző szín }\end{array}$ & 4,13 & 4,18 \\
\hline \multirow{4}{*}{ Állomány } & Kemény & 2,40 & 2,88 \\
\hline & Lágy & 3,18 & 2,70 \\
\hline & Rugalmas & 3,28 & 3,40 \\
\hline & Morzsás & 2,83 & 2,20 \\
\hline
\end{tabular}

Az íz esetében három jellemző volt feltüntetve a bírálati lapon, ahol az intenzitás, az adott kenyértípusra jellemző, valamint az esetleges idegen íz érzetét kellett megállapítaniuk a résztvevőknek. A két minta összehasonlítása során intenzívebb ízünek érezték a résztvevők a biokenyeret. Emellett úgy vélték, hogy sokkal inkább a „B” jelzésü minta íze emlékeztet az adott kenyértípusra. A megszokottól eltérő, idegen ízt a konvencionális kenyérnél érzékeltek erőteljesebben a bírálók. Egy résztvevő tett megállapítást arról, hogy keserű utóízt érzett a biogazdálkodásból származó mintánál.

$\mathrm{A} z$ illat megítélésének folyamán az intenzitást és az idegen illatokat kellett meghatározniuk a résztvevőknek. Az értékelés alapján elmondható, hogy intenzívebb illatúnak bizonyult a szokványos kenyér, de a csoporttagok számukra ismeretlen illatokat is inkább ehhez a mintához társítottak.

A színintenzitás tekintetében a biokenyér bizonyult ideálisabbnak, valamint úgy gondolták a résztvevők, hogy ennek a mintának van inkább az adott kenyértípusra jellemző színe.

$\mathrm{A} z$ állag megítélése során négy tulajdonság alapján kellett értékelniük a mintákat a bírálóknak. A csoporttagok úgy gondolták, hogy a biogazdaságból származó minta tömörebb, keményebb, mint a konvencionális kenyér, illetve rugalmasabb is. A szokványos kenyeret ezzel szemben lágyabbnak és morzsásabb szerkezetünek ítélték meg.

A kenyérminták megítélését és kedveltségét a 2. ábra foglalja össze.

\section{2. ábra: A kenyérminták megítélése és kedveltsége ötfokozatú} skálán $(\mathrm{N}=40)$

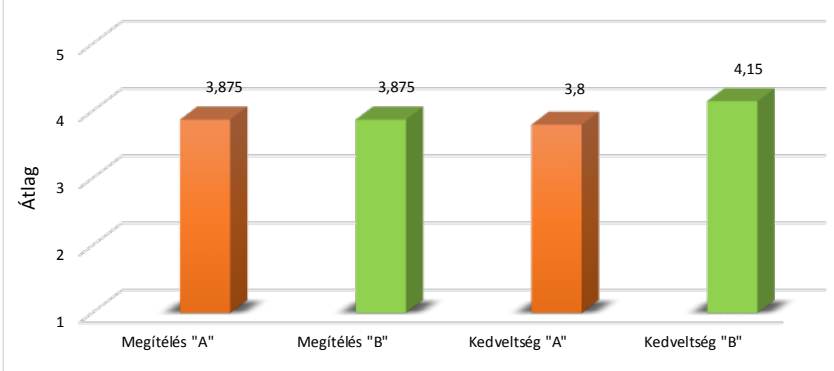

A kenyerek vonatkozásában az „A” és a „B” jelzésű minta megítélése nem mutatott eltérést. A kedveltség megállapításakor azonban a résztvevők a „B” jelü, azaz a biogazdaságból származó terméket részesítették előnyben.

A kérdőívben szereplő kérdésekre adott válaszok alapján megállapítható, hogy a kóstolás alapján a 40 fós csoport tagjai közül 21-en a biogazdaságból, míg 19-en a hagyományos gazdálkodásból származó mintát találták jobbnak. A vásárlás tekintetében is hasonlóan alakult az arány, mert a minták közül 21 fó szívesebben vásárolná meg a bioterméket. A vakteszt során érzékelt jellemzők alapján pedig a csoport egyik fele (20 fó) a konvencionális, a másik fele viszont az ökotermékért lenne hajlandó magasabb árat megfizetni. Az eredet ismeretének hiányában a bírálók közül 21-en helyesen megállapították, hogy a „B” jelü minta származott biogazdaságból és az „A” jelzésű a szokványos gazdaságból. A termékek származásának ismerete két bíráló esetében negatív hatással volt a vásárlási hajlandóságra. Ennek oka, hogy a biokenyeret drágábbnak ítélték meg a résztvevők. 


\section{KÖVETKEZTETÉSEK ÉS JAVASLATOK}

A primer kutatás eredményei alapján megállapítható, hogy az érzékszervi tulajdonságok alapján a vizsgált populációban megkülönböztethetőek a szokványos és az ökoélelmiszerek. A szakértői mélyinterjú, a fókuszcsoportos interjúk és a vakteszt eredményei is alátámasztják az előbbi megállapítást. A külső ismertetőjegyek alapján a védjegy segíti a megkülönböztetést, a belső tulajdonságok terén viszont az élvezeti érték. A vaktesztben a bírálók az organoleptikus tulajdonságok tekintetében képesek voltak különbséget tenni a két eltérő előállítási mód termékei között. A termékcsoportok összehasonlítása során a tej és a kenyér esetében is az ökológiai előállítású élelmiszereket részesítették előnyben a résztvevők.

A két különböző előállítási mód termékei közötti differenciát célszerű lenne kiemelni, mert az érzékszervi tulajdonságok a fogyasztók számára kiemelten fontosak egy-egy élelmiszer kiválasztásánál. A biotermékek organoleptikus jellemzői alkalmasak lehetnek a védjegy által közvetített pozitív imázs erősítésére. A csomagolás, illetve a védjegy pedig akkor keltené fel még jobban az emberek figyelmét, ha több ismerettel rendelkeznének az ökotermékekről. A címke önmagában nem elegendő, mert szükséges, hogy a szkeptikus gondolkodást a tanúsító szervezetek, az előállítás és a feldolgozás kapcsán enyhíteni lehessen. A bioélelmiszerekkel kapcsolatos bizalmatlanságot a bővebb információtartalom segítené megváltoztatni, amely hathatós kommunikációval erősíthető gyártói, feldolgozói, érdekképviseleti és fogyasztói oldalról egyaránt.

\section{KÖSZÖNETNYILVÁNÍTÁS}

A közlemény elkészítését az EFOP 3.6.1-16-2016-0007 azonosító számú „Intelligens szakosodási program a Kaposvári Egyetemen" c. projekt támogatta.

\section{5. ÖSSZEFOGLALÁS}

A fogyasztók számára fontosak az élelmiszerek érzékszervi jellemzői, melyek közül a legjelentősebb tényező az ízlelés. A különböző előállítási módok azonban jelentősen befolyásolhatják ezeket a tulajdonságokat. Vizsgálatunk során a szokványos és az ökológiai gazdálkodásból származó termékek között kerestünk eltéréseket. Célunk az organikus élelmiszerek piaci potenciáljának növeléséhez való hozzájárulás volt, a termékértékükre, termékélményükre hivatkozva. A kvalitatív kutatás során először dietetikussal készítettünk személyes interjút, majd két fókuszcsoportos beszélgetésre került sor. A kvantitatív kutatás folyamán 40 fó értékelte a konvencionális és biogazdálkodásból származó tej- és kenyérmintákat vakteszt keretében. A primer kutatás eredményei alapján megállapítható, hogy lehetséges különbséget tenni a két eloállitási mód termékei között. A dietetikus és a két fókuszcsoport résztvevői szerint nagy eltérések vannak a szokványos és a bioélelmiszerek között a beltartalmi és az élvezeti érték tekintetében is, külsőleg pedig a védjegy segíti az ökotermékek azonosítását. A vakteszt során a tejek esetében a biogazdálkodásból származó minta megítélése és kedveltsége felülmúlta a szokványos mintáét. Ízanyagokban gazdagabbnak és édesebbnek itélték meg az ökotejet, valamint intenzívebb színt és zsírosabb állagot is éreztek a szokványos tejhez képest. A kenyerek esetén is jobban kedvelték az ökológiai gazdálkodásból származó terméket a résztvevők. A biokenyér ízét és színét intenzívebbnek ítélték meg, állagát pedig tömörebbnek és rugalmasabbnak érezték a bírálók. Éppen ezért a két különböző előállítási mód termékei közötti differenciát célszerű kiemelni a termékértékesítés során. Az ökoélelmiszerek organoleptikus jellemzői alkalmasak lehetnek a védjegy által közvetített pozitív imázs erősítésére, ízélménye miatt pedig a vásárlói lojalitás növelésére.

\section{IRODALOM}

Annett, L., Muralidharan, V., Boxall, P., Cash, S. \& Wishmer, W. (2008). Influence of Health and Environmental Information on Hedonic Evaluation of Organic and Conventional Bread. Journal of Food Science, 73(4), 50-57. doi: 10.1111/j.17503841.2008.00723.x .

Dörnyei, K. (2008). Bioélelmiszer fogyasztási szokások. Marketing \& Menedzsment, 42(4), 35-40.

Duxbury, D. (2005). Sensory Evaluation Provides Value. Food Technology, 58(5), 68-72.

Fillion, L. \& Arazi, S. (2002). Does organic food taste better? A claim substantiation approach. Nutrition \& Food Science, 32(4), 153-157. doi: 10.1108/00346650210436262

Gergely, É., Szabó, B. \& Balázs, K. (2014). Az egészség- és környezettudatosság, valamint az értékrend hatása a bioélelmiszer-fogyasztásra. Marketing \& Menedzsment, 48(4), 27-37.

Haas, R., Sterns, J., Meixner, O., Nyob, D.-I. \& Traar, V. (2013). Do US Consumers' Perceive Local and Organic Food Differently? An Analysis Based on Means-End Chain Analysis and Word Association. Int. J. Food System Dynamics, 4(3), 214-226.

Hofer, M. (2009). Bioélelmiszerek fogyasztásának tendenciája Magyarországon. [Doktori értekezés]. Győr: Széchenyi István Egyetem Multidiszciplináris Társadalomtudományi Doktori Iskola.

Hofer, M. (2010). A biofogyasztási értékrend alakulása. In Papp-Váry, Á. \& Csépe, A. (szerk.), Új Marketing Világrend: MOK 2010: a Magyar Marketing Szövetség Marketing Oktatók Klubja 16. országos konferenciája. (pp. 352-354). Budapest: Budapesti Kommunikációs és Üzleti Főiskola.

Hultén, B. (2015). Sensory Marketing: Theoretical and Empirical Grounds. (1. kiad.). New York: Routledge.

Huszka, P. \& Polereczki, Zs. (2008). Alapélelmiszerek fogyasztása és vásárlása, valamint a döntést meghatározó tényezők vizsgálata Nyugat-Dunántúlon. Élelmiszer, Táplálkozás és Marketing, 5(2-3), 17-18.

Kiss, M., Kontor, E. \& Kun, A. I. (2015). A biominősítés hatása a fogyasztók érzékelésére és attitűdjére csokoládék esetén. In Bíró-Szigeti, Sz., Petruska I., Szalkai Zs., Kovács, I. \& Magyar, M. (szerk.), Az Egyesület a Marketing Oktatásért és Kutatásért XXI. Országos Konferenciájának Tanulmánykötete. (pp. 208216). Budapest: Budapesti Müszaki Egyetem.

Kiss, M., Kontor, E. \& Kun, A. I. (2016). Az organikuscímke-hatás a marketing irodalomban: Imázstranszfer, halo-hatás és jelzés. Táplálkozásmarketing, 3(1), 61-71.

Lindstrom, M. (2005). Broad sensory branding. Journal of Product \& Brand Management, 14(2), 84-87. doi: 10.1108/10610420510592554

Németh-T., A., Vincze-Tóth, J., Hegyi, J. \& Troján, S. (2014). Funkcionális élelmiszerek- fogyasztói, vásárlói preferen- 
ciák. Acta Agronomica Óváriensis, 56(1), 29-42. doi: 10.17108/ aao.2014.01.03

Panyor, Á. (2007). A különleges élelmiszerek piacnövelési lehetőségei megkérdezések tükrében. [Doktori értekezés]. Budapest: Budapesti Corvinus Egyetem Interdiszciplináris Doktori Iskola.

Pawel, B. (2016). Organic food consumption in Poland: Motives and barriers. Appetite, 105, 737-746. doi: 10.1016/j.appet.2016.07.012

Szente, V. (2004). Organikus élelmiszerek fogyasztási és vásárlási szokásainak vizsgálata Magyarországon. Élelmiszer, Táplálkozás és Marketing, 1(1), 101-106.

Szente, V.\& Torma, D. (2015). Organic food purchase habits in Hungary. Journal of Economic Development, Environment and People, 4(1), 32-40. doi: 10.26458/jedep.v4i1.96
Szente, V., Szakály, Z. \& Széles, G. (2011). Ökoélelmiszerek megítélése Magyarországon - alakuló fogyasztói tudatosság? Gazdálkodás, 55(5), 512-517.

Thøgersen, J., Pedersen, S., Paternoga, M., Schwendel, E., \& Aschemann-Witzel, J. (2017). How important is country-of-origin for organic food consumers? A review of the literature and suggestions for future research. British Food Journal, 119(3), 542-557. doi: 10.1108/bfj-09-2016-0406

Tisza, A. (2016. március). Növekszik az egészségesnek tartott élelmiszerkategóriák fogyasztása. Sajtóközlemény. [GFK Sajtóközlemény. Budapest: GFK Hungária Piackutató Intézet.] Letöltés dátuma: 2017. 12. 12. forrás: https://www.askgfk.hu/fileadmin/user_upload/banners/news/20160302_GfK_Egeszsegtudatossag_az_etkezesben.pdf 